\title{
Recruiting Underrepresented Minority and Low-Income High School Students into Dentistry While Educating Dental and Dental Hygiene Students About Academic Careers
}

\author{
Marita R. Inglehart, Dr. phil. habil.; Stephen J. Stefanac, D.D.S., M.S.; \\ Kimberly P. Johnson, Ed.M.; Anne E. Gwozdek, R.D.H., M.A.; Kenneth B. May, D.D.S., \\ M.S.; William Piskorowski, D.D.S.; Marilyn W. Woolfolk, D.D.S., M.P.H.
}

Abstract: The objectives of this project were to create a program that would expose underrepresented minority (URM) and low income (LI) high school students to dental professions and provide an opportunity for dental and dental hygiene students from URM/LI groups to be engaged in teaching activities. Data were collected from participants during the school years 2009-10 (high school students: $\mathrm{N}=23$, dental students: $\mathrm{N}=21$, dental hygiene students: $\mathrm{N}=5)$ and 2010-11 $(\mathrm{N}=27, \mathrm{~N}=11, \mathrm{~N}=3$, respectively). The students participated in fifteen Saturday sessions from October through March each year. The data showed that, from the beginning, mentees and mentors were very interested in participating in the program and getting to know each other. Lectures, general program activities, and patient-related events such as organizing a health fair and shadowing during two outreach clinics were evaluated positively by mentees and mentors. The end of program evaluations showed that the program and the mentee-mentor relationships were rated very positively and that the mentees had an increased interest in oral health-related careers. In conclusion, creating opportunities for URM/LI high school students to explore dental careers and for dental and dental hygiene students to engage in teaching resulted in positive experiences for both groups.

Dr. Inglehart is Professor, Department of Periodontics and Oral Medicine, School of Dentistry, and Adjunct Professor of Psychology, Department of Psychology, College of Literature, Science, and Arts, University of Michigan; Dr. Stefanac is Associate Dean for Patient Care and Professor, Department of Periodontics and Oral Medicine, University of Michigan School of Dentistry; Ms. Johnson is Director, Chicago Academic Achievement Program, University of Chicago; Ms. Gwozdek is Clinical Assistant Professor in Dentistry, Department of Periodontics and Oral Medicine, University of Michigan School of Dentistry; Dr. May is Associate Professor of Dentistry, Department of Biologic and Materials Sciences, and Director of Office for Multicultural Affairs and Recruitment, University of Michigan School of Dentistry; Dr. Piskorowski is Assistant Dean for Community-Based Dental Education and Clinical Associate Professor, University of Michigan School of Dentistry; and Dr. Woolfolk is Emeritus Professor of Dentistry and Assistant Dean for Student Services, University of Michigan School of Dentistry. Direct correspondence and requests for reprints to Dr. Marita R. Inglehart, Department of Periodontics and Oral Medicine, University of Michigan School of Dentistry, 1011 North University Avenue, Ann Arbor, MI 48109-1078; 734-763-8073; mri@umich.edu.

Keywords: dental education, dental students, dental hygiene students, high school students, student recruitment, student diversity, dental faculty, underrepresented minorities

Submitted for publication 5/8/13; accepted 9/9/13

$\mathrm{T}$ The profession of dentistry in the United States faces three major interrelated challenges. The first challenge is that specific groups such as patients from socioeconomically disadvantaged and/ or minority populations experience high amounts of dental disease and problems with access to dental care. ${ }^{1}$ The second challenge is the lack of racial/ ethnic diversity among dental care providers. ${ }^{2}$ This challenge is closely related to the first challenge because research has shown that the lack of diversity among health care providers contributes to health disparities and problems with access to health care for patients from disadvantaged groups. ${ }^{3-6}$ For example, the Sullivan Commission reported that 62 percent of African American patients in the United States are treated by 5 percent of African American dentists, while only 10.5 percent of African American patients are treated by European American dentists. ${ }^{2}$ Increasing the number of underrepresented minority (URM) dentists is therefore an important objective. ${ }^{7}$ The third challenge, which is related to both of the other challenges, is the shortage of dental faculty members in general and the significantly lower numbers of URM faculty members. 
In January 2009, the W.K. Kellogg Foundation in collaboration with the American Dental Education Association (ADEA) called for proposals from U.S. dental schools interested in designing educational programs to address these three challenges. The University of Michigan School of Dentistry submitted a proposal that received funding, and in February 2009, the development of the Ypsilanti High School Recruitment Through Engagement Program began. The key objectives of this program were 1) to recruit URM and low income (LI) high school students into dental professions, 2) to engage dental and dental hygiene students in developing and leading educational activities with the high school students, and 3) to explore how to provide oral health care services to underserved patients in this community.

To achieve the first objective, URM/LI high school students were recruited into the Ypsilanti program. The goal was to engage them in activities that would motivate them to consider dental professions as potential careers. This objective is related to the fact that the number of URM students in U.S. dental schools is not proportional to the number of minority individuals in the nation. ${ }^{8}$ To address this problem, dental schools have developed prematriculation programs for URM/LI college students ${ }^{8-13}$ and have established postbaccalaureate programs to support URM/LI college graduates in preparing to apply to dental schools. ${ }^{14,15}$ However, exposing students to the dental profession as early as high school could be crucial for recruiting them into dental schools. ${ }^{13,16}$ Reaching out to high school students offers the opportunity to provide them with role models and inform them about dental careers and the academic preparation necessary to enter these careers. ${ }^{17}$ Outreach to high school students can also provide opportunities for academic enrichment to help increase their competitiveness for the college admissions process. ${ }^{13,18}$ Additionally, the participation and support of parents are important in nurturing the career aspirations and interests of URM high school students. ${ }^{13,19}$

In consideration of these research findings, the Ypsilanti program was designed to provide high school students with role models in the form of predoctoral dental and dental hygiene students and faculty members, many of whom were from URM groups. Program activities were developed to encourage the high school students to think about the educational path to college and professional programs related to dentistry. The students' parents were invited to attend an orientation session at the beginning of the program, the health fair the students organized, and the end of program celebration. The parents also received weekly letters throughout the duration of the program, informing them about activities.

The second objective of the program was to engage dental and dental hygiene students in developing and leading educational activities with the high school students and mentoring them, with the intention of increasing the professional students' interest in academic careers. The shortage of dental school faculty in the United States is one of the most critical challenges faced by the profession. ${ }^{20,21}$ This problem is likely to increase with the opening of additional dental schools. ${ }^{22}$ Furthermore, the lack of diversity among dental faculty members is a serious concern, with minorities accounting for less than 9 percent of the total. ${ }^{2}$ One study found that fourth-year dental students who planned to pursue academic careers did so as a result of having knowledge about academic careers and teaching experiences ${ }^{23}$ while another study showed that a lack of mentoring and of knowledge about academic career paths kept students from considering these possibilities. ${ }^{24}$ In response to the faculty shortage, Bertolami urged dental schools to expose students and residents to academic careers. ${ }^{25}$ Programs are therefore needed to identify, support, and mentor dental students who indicate an interest in academia. ${ }^{26}$ Previous studies found that teaching assistantships, fellowships, and peer tutoring opportunities were helpful for the recruitment and retention of faculty and thus should be elements of academic track programs. ${ }^{27,28}$ Teaching opportunities for dental students are one important way to raise their awareness concerning the rewards and benefits of academic dentistry. ${ }^{25,29,30}$

Based on these considerations, dental and dental hygiene students with an interest in mentoring high school students and developing and conducting the program activities were recruited to participate in our program. The elective courses Educational Practicum I (in the fall term) and II (in the winter term) for third- and fourth-year dental students (Dent $753 / 754$ and Dent $853 / 854$, respectively) and a field practicum for dental hygiene students (Psych 323) were developed that consisted of weekly lunchtime sessions prior to the Saturday program sessions. During these preparatory meetings, the students discussed how to optimally mentor the high school students, and they were informed about the upcoming topics to be covered in the next Saturday session. They then volunteered to be responsible for organizing program activities such as leading discussions, facilitating demonstrations and exercises, and giving 
PowerPoint presentations. Providing our students with these extensive teaching experiences was seen as encouraging and supporting their academic career considerations.

The third objective was to engage the high school students in community outreach by organizing much-needed oral care for members of their local community. ${ }^{1}$ Raising these students' awareness of the need for increased oral care services in their community was achieved in two ways. First, the high school students collaborated with the dental and dental hygiene students and faculty members in planning and conducting a health fair at their high school. Second, the high school students were able to participate as health educators and shadow their mentors during two volunteer clinics at the dental school.

These three program objectives were designed to align with the three challenges facing the dental profession and the dental education community (Figure 1). Program evaluations were used to assess the degree to which the Ypsilanti program activities were successful in achieving these objectives. This article describes how the evaluations were conducted and their results.

\section{Methods}

This study was approved by the Institutional Review Board for the Behavioral and Health Sciences at the University of Michigan. Twenty-three high school student mentees and twenty-six dental and dental hygiene student mentors participated in the 2009-10 school year, and twenty-seven mentees and fourteen mentors participated in the 2010-11 school year. Table 1 provides an overview of the mentees' and mentors' characteristics. The high school students were in grades nine through twelve (grade 9: $\mathrm{N}=10$; grade 10: $\mathrm{N}=3$; grade 11 : $\mathrm{N}=14$; grade 12: $\mathrm{N}=20)$, and the mentors were third- $(\mathrm{N}=23)$ and fourth-year $(\mathrm{N}=9)$ dental students and third- $(\mathrm{N}=1)$ and fourth-year $(\mathrm{N}=7)$ dental hygiene students. Twenty-eight of the mentees were male and twentytwo were female; ten of the mentors were male and thirty were female. Most of the high school students were African American (2009-10: 83 percent African American, 17 percent European American; 2010-11: 85 percent African American, 11 percent Middle Eastern, 4 percent European American). The dental hygiene and dental students were from more diverse

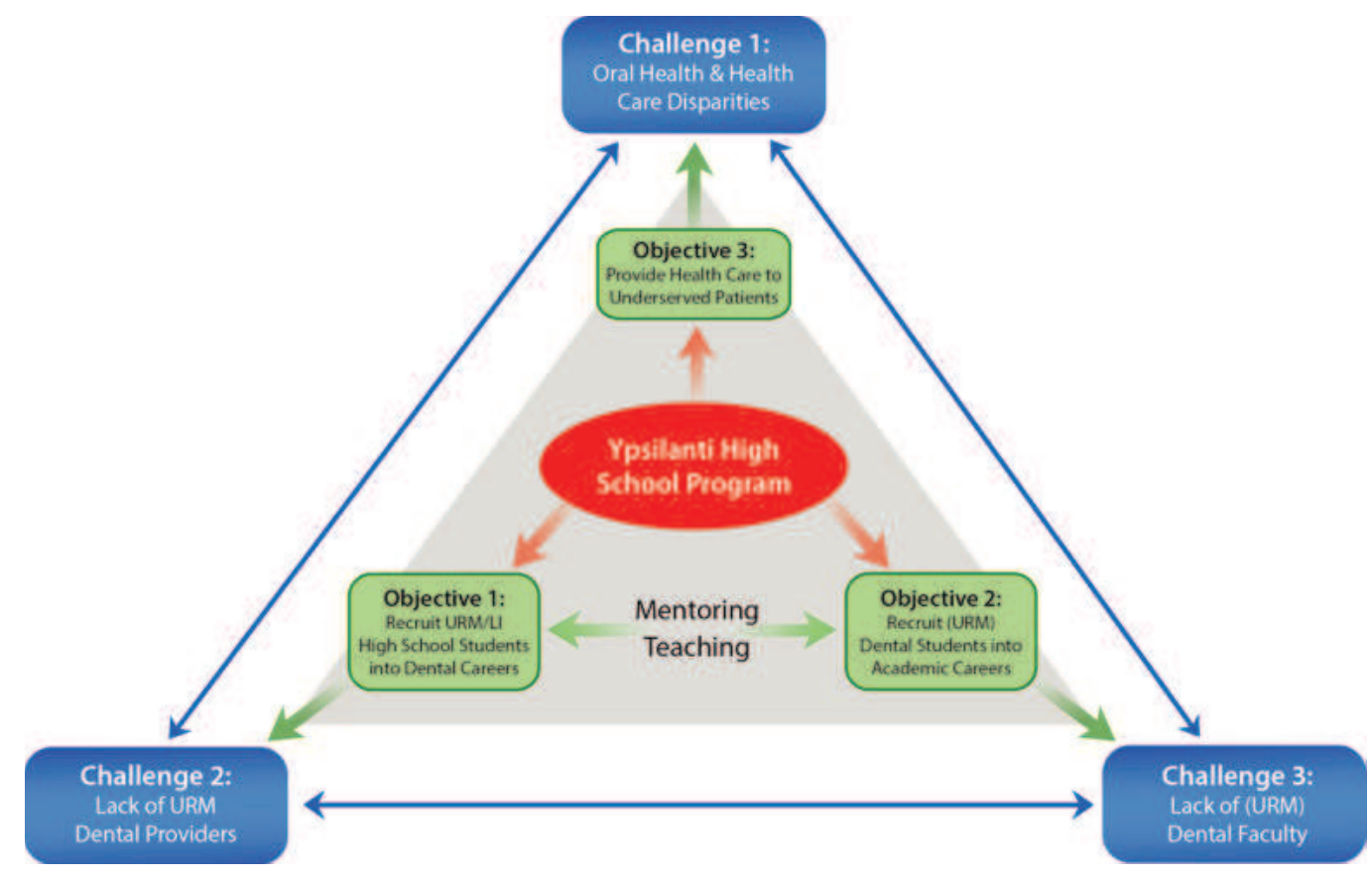

Figure 1. Overview of program objectives to address challenges in the dental profession 
Table 1. Characteristics of mentors and mentees in 2009-10 and 2010-11

\begin{tabular}{|c|c|c|c|c|}
\hline & \multicolumn{2}{|c|}{ School Year 2009-10 } & \multicolumn{2}{|c|}{ School Year 2010-11 } \\
\hline & Mentees & Mentors & Mentees & Mentors \\
\hline Number of students & 23 & 26 & 27 & 14 \\
\hline $\begin{array}{l}\text { Number of students who } \\
\text { full credit } \\
\text { half credit } \\
\text { no credit }\end{array}$ & $\begin{array}{c}17 \\
1 \\
5\end{array}$ & & $\begin{array}{c}12 \\
5 \\
10\end{array}$ & \\
\hline $\begin{array}{l}\text { High school grade } \\
9 \text { th grade } \\
\text { 10th grade } \\
11 \text { th grade } \\
12 \text { th grade }\end{array}$ & $\begin{array}{l}7(33 \%) \\
1(5 \%) \\
6(29 \% \\
7(33 \%)\end{array}$ & & $\begin{array}{c}3(12 \%) \\
2(8 \%) \\
8(31 \%) \\
13(50 \%)\end{array}$ & \\
\hline $\begin{array}{l}\text { Dental school year } \\
\text { DHyg } 3 \\
\text { DHyg } 4 \\
\text { D3 } \\
\text { D4 }\end{array}$ & & $\begin{array}{c}1(4 \%) \\
4(15 \%) \\
15(58 \%) \\
6(23 \%)\end{array}$ & & $\begin{array}{c}0 \\
3(21 \%) \\
8(57 \%) \\
3(21 \%)\end{array}$ \\
\hline $\begin{array}{l}\text { Gender } \\
\text { Male } \\
\text { Female }\end{array}$ & $\begin{array}{c}17(74 \%) \\
6(26 \%)\end{array}$ & $\begin{array}{c}6(23 \%) \\
20(77 \%)\end{array}$ & $\begin{array}{l}11(41 \%) \\
16(59 \%)\end{array}$ & $\begin{array}{c}4(29 \%) \\
10(71 \%)\end{array}$ \\
\hline $\begin{array}{l}\text { Ethnicity } \\
\text { African American } \\
\text { Asian American } \\
\text { European American } \\
\text { Latino/a } \\
\text { Middle Eastern/Indian }\end{array}$ & $\begin{array}{c}19(83 \%) \\
0 \\
4(17 \%) \\
0 \\
0\end{array}$ & $\begin{aligned} 10 & (39 \%) \\
1 & (4 \%) \\
10 & (39 \%) \\
2 & (8 \%) \\
3 & (12 \%)\end{aligned}$ & $\begin{array}{c}23(85 \%) \\
0 \\
1(4 \%) \\
0 \\
3(11 \%)\end{array}$ & $\begin{array}{c}8(57 \%) \\
0 \\
4(29 \%) \\
1(7 \%) \\
1(7 \%)\end{array}$ \\
\hline
\end{tabular}

Note: Percentages may not total $100 \%$ due to rounding.

races and ethnicities: in 2009-10, 39 percent African American, 39 percent European American, 12 percent Middle Eastern, 8 percent Latino/a, and 4 percent Asian American; in 2010-11, 57 percent African American, 29 percent European American, 7 percent Latino/a, and 7 percent Middle Eastern.

\section{Procedures and Analysis}

The recruitment of third- and fourth-year dental and dental hygiene student mentors started at the beginning of the school years in August 2009 and August 2010. An email was sent describing the program and asking all interested students to attend a lunchtime information session about the program and their roles as mentors and teachers. Students who made a commitment to participate were then invited to a two-hour orientation session in early September. During this orientation session, they responded to a baseline survey. In Year 1, the mentors received a small stipend for their efforts. In Year 2, they received one academic credit each for enrolling in the elective course.

The recruitment of the mentees began with identifying high schools with high numbers of URM/ LI students. Ypsilanti High School was selected because Ypsilanti, MI, is a city close to Ann Arbor, MI, in Washtenaw County. Ypsilanti had approximately 20,000 citizens in 2011 , with minority groups making up approximately 40 percent. ${ }^{31}$ The estimated median household income of Ypsilanti in 2011 was $\$ 33,699$, which was significantly lower than the average median household income of $\$ 60,895$ in the state of Michigan. ${ }^{32}$ The graduation rate for high school students in the Ypsilanti School District is 66 percent, and 26.4 percent of the population live below the Federal Poverty Level. ${ }^{33,34}$

The superintendent of the Ypsilanti School District was contacted; once he had agreed to the 
program, a collaboration contract was developed for each year, signed by the superintendent, the high school principal, and the dean of the dental school. During the first week of October 2009 and 2010, the dental and dental hygiene student mentors travelled to Ypsilanti High School on a weekday morning at 6:30 a.m. When classes started at 7:30 a.m., the mentors visited the classrooms and presented information about oral health-related issues and the upcoming Saturday program for about fifteen to twenty minutes in each class. Each mentor visited about three classrooms, which enabled the mentors to visit most classes in session at that time.

During the classroom visits, the mentors handed out program information flyers to the high school students. The students were invited to attend an orientation session with their parents or guardians if they were interested in participating in the program. At this orientation session, the dental and dental hygiene students and faculty and the high school administrators informed the parents/guardians and high school students about the program. They were told the program would take place on Saturdays from 9:00 a.m. to 12:30 p.m. From October through December, the sessions took place in the Ypsilanti High School library, and from January through March, the sessions took place at the University of Michigan School of Dentistry in Ann Arbor, MI. Only students whose parents/guardians attended this first orientation session and signed a consent form were allowed to participate. High school students who attended all fifteen Saturday sessions or had limited excused absences received one health credit on their Ypsilanti High School transcript for their participation. Surveys were completed at the beginning of the first session and at the end of each of the fifteen Saturday sessions by both the mentees and the mentors.

The surveys were designed to assess the mentees' and mentors' interest in the program, to evaluate the different program activities, and to assess the degree to which both mentees and mentors found the mentoring activities helpful. Identical questions were included in the mentee and mentor surveys to allow comparing the responses of the two groups. In addition, the high school students answered questions concerning how interested they were in health-related careers. All surveys were no longer than one page and consisted of about five to ten closed-ended questions (most with five-point rating scales) and one or two open-ended questions.

The data were analyzed with SPSS (Version 19). Descriptive statistics such as frequency distribu- tions, percentages, means, standard deviations, and ranges were computed to provide an overview of the responses. Independent sample t-tests and analyses of variance were used to compare the responses to the rating scale questions of the mentees and mentors in each of the two years. Chi-square analyses were used to compare the responses to the categorical questions of the two groups of participants in the two years.

\section{Key Features of Program}

This program was developed in response to the January 2009 call for proposals issued by the W.K. Kellogg Foundation and ADEA. This call announced that these organizations would jointly fund one-year programs at three different dental schools that developed programs to educate URM middle and high school students about oral health careers, while also bringing oral health care to children in low-income communities. The University of Michigan received funding for one year (June 1, 2009, to May 31, 2010) plus a three-month no cost extension until August 31,2010 . In the second year, 2010-11, the program was not funded by the grant; however, the Center for Educational Outreach at the University of Michigan provided funds for busses to transport the high school students to the School of Dentistry during the winter months. Once the recruitment activities had taken place, the program activities were developed jointly between the principal investigators (MRI and SJS), the co-investigators ( $\mathrm{AG}, \mathrm{KM}$, and $\mathrm{MW}$ ), and the dental and dental hygiene student mentors. The first author met with the mentors weekly to discuss how to plan the upcoming Saturday session. The mentors then prepared PowerPoint presentations, facilitated exercises, and prepared demonstrations, while building mentoring relationships with individual high school students throughout all the activities. Table 2 provides the timeline of the program and lists specific program activities for the first year. Activities on the fifteen Saturdays during the second year covered the same topics.

One essential component of the fall activities was to engage the high school students in planning a health fair for children and their parents at their high school with the goal of bringing oral health care to their own community. These events took place on a Saturday in November in 2009 and 2010. The high school students organized the advertising for the fair and prepared all educational activities. On the day of the health fair, the students met at 9 a.m. and set up an oral health screening clinic. The dental school 


\section{Table 2. Timeline of the program}

\begin{tabular}{|c|c|}
\hline Time & Activity \\
\hline 2/2009-8/2009 & Program preparations \\
\hline 9/2009-12/2010 & Year 1: fall semester activities \\
\hline October 1, 2009 & Recruitment visit to Ypsilanti High School \\
\hline October 5, 2009 & Parent/guardian information evening \\
\hline Saturday 1 & Getting to know each other and dental careers \\
\hline Saturday 2 & Oral health and dentistry for children and preparing for health fair \\
\hline Saturday 3 & Oral health and dentistry for adults \\
\hline Saturday 4 & Oral health education and preparing for health fair \\
\hline Saturday 5 & Oral health fair for children and parents \\
\hline Saturday 6 & Debriefing of health fair activities and outlook \\
\hline $1 / 2010-3 / 2010$ & Year 1: winter semester activities on theme "Getting to know the life of a dentist/dental hygienist" \\
\hline Saturday 7 & HIPAA certification, patient care coordinators, relationship with patients \\
\hline Saturday 8 & Instrument dispensing and sterilization and working in a simulation lab \\
\hline Saturday 9 & Clinical chart information, working with radiographs, clinic tours \\
\hline Saturday 10 & Preparing for "Give Kids a Smile" event \\
\hline Saturday 11 & "Give Kids a Smile" clinic \\
\hline Saturday 12 & Debriefing of clinical activities and dental specialties \\
\hline Saturday 13 & Preparation for Taft Clinic (volunteer clinic for adult dental patients) \\
\hline Saturday 14 & Taft Clinic for adult dental patients \\
\hline Saturday 15 & Debriefing of clinical activities and end of program celebration \\
\hline $6 / 2010-8 / 2010$ & Year 1: summer research experience \\
\hline 9/2010-12/2010 & $\begin{array}{l}\text { Year 2: fall semester activities } \\
\text { - High school-based activities } \\
\text { - Elective courses: Dent } 753(\mathrm{~N}=8) \text {, Dent } 853(\mathrm{~N}=5) \text {, Psych } 323(\mathrm{~N}=3)\end{array}$ \\
\hline $1 / 2011-3 / 2011$ & $\begin{array}{l}\text { Year 2: winter semester activities } \\
\text { - Dental school-based activities } \\
\text { - Elective courses: Dent } 754(\mathrm{~N}=8) \text {, Dent } 854(\mathrm{~N}=5) \text {, Psych } 323(\mathrm{~N}=3)\end{array}$ \\
\hline $6 / 2011-8 / 2011$ & Year 2: summer research experience \\
\hline
\end{tabular}

provided all needed dental supplies. Pediatric dental residents and faculty members volunteered their time to supervise the dental and dental hygiene students who conducted screenings of the pediatric patients. In 2009, vouchers for free dental care at the dental school clinics and a local pediatric dentist's office were handed out to the parents whose children needed care. In 2010, information was distributed about dentists and dental clinics that provided care for children covered by Medicaid.

The winter term activities took place at the School of Dentistry on Saturdays from 9 a.m. to 12:30 p.m. and had the general theme "Getting to know the life of a dentist/dental hygienist." These activities started with making sure that all high school students were HIPAA-certified. They then learned about how patients were welcomed to the dental school clinics and how dental and dental hygiene students get ready for their patients. The mentees were introduced to instrument dispensing and sterilization, toured the sterilization unit, and visited the predoctoral dental clinics, the pediatric and orthodontic clinics, and the Patient Admission and Emergency Services (PAES) clinic. They observed how their mentors set up a cubicle and then set up a cubicle themselves under their mentors' supervision. The mentees learned about the importance of clinical chart information and patient's medical background. They received information about caries and periodontal disease, how these diseases were recorded in the charts, and how treatment planning activities unfold. Mentees had an opportunity to observe how radiographs were taken on a manikin and were introduced to how radiographs are interpreted. They also engaged in a Simulation Lab activity and enjoyed a mirror drawing activity. Several dental faculty members talked to the students 
about their work as specialists in pediatric dentistry, orthodontics, prosthodontics, periodontics, or public health dentistry. The mentees had an opportunity to shadow their mentors during one volunteer clinic for adult dental patients and one free "Give Kids a Smile" dental clinic for pediatric dental patients. A graduation ceremony took place on the last Saturday of the program.

\section{Results}

The project's goal was to have a maximum of twenty-five mentees participate in the program in each of the academic years. Twenty-three mentees participated in the first year and twenty-seven mentees in the second year (Table 1). In the first year, the goal was to match each mentee with one mentor, so twenty-six mentors were recruited into the program. However, in the second year only fourteen mentors self-identified to participate, so two mentees were assigned to one mentor each. The program consisted of fifteen sessions, with six sessions in the fall term and nine sessions in the winter term. Seventeen mentees received full credit and one mentee received half a credit in the first year; twelve mentees received full credit and five mentees received half a credit during the second year (Table 1).

Baseline data were collected from a survey administered during a program orientation session for the mentors as well as from a survey distributed to mentors and mentees at the beginning of the first Saturday class (Table 3). The responses showed that the vast majority of the mentors agreed or strongly agreed that they were very interested in being a mentor, that they were very well informed about dentistry and dental hygiene, that they would love to talk to high school students about their chosen profession, and that they were happy to participate in the dental outreach program with these students and looked forward to talking with them. Most of the mentors agreed or strongly agreed that they considered being a dentist/dental hygienist the most satisfying career for themselves.

The mentors also responded to a baseline survey at the beginning of the first Saturday session in each of the two years. The absolute majority of the students again agreed or strongly agreed that they were very interested in participating in this program, that they would like to talk to the mentees and wanted to participate in the dental outreach program, and that they looked forward to developing this program for the high school students. The mentees also responded to a short baseline survey at the beginning of the first Saturday session. The majority of the mentees agreed or strongly agreed that they were very interested in participating in this program and wanted to talk to the dental and dental hygiene students and to participate in this program.

At the end of each of the fifteen Saturdays, the mentors and mentees responded to a short survey. Some of these surveys had the same general questions such as "I look forward to the next Saturday," "Today was interesting/went well," and "I got to know the mentors/mentees better." These three questions were asked on six of the fifteen Saturday events (Table $4)$. Both mentees and mentors agreed strongly on average with the statement that they looked forward to the next Saturday and responded with "strongly agree" and "agree" to the statement "Today was interesting/went well." On most Saturdays in both years, the mentees and the mentors indicated that the program allowed them to get to know their mentee or mentor better.

The program activities fell into three categories. The first category consisted of presentations about dentistry-related topics such as lectures about the dental specialties, oral health care in general, and aspects of the practice of dentistry such as sterilization, infection, the use of clinical charts, and taking radiographs. These lectures were either prepared and presented by the dental and dental hygiene students or by visiting dental and dental hygiene faculty members. Table 5 provides an overview of the mentees' and mentors' evaluation of these lectures in each of the two years. Both mentees and mentors expressed a high level of interest in the information provided. They disagreed very rarely about how interesting a topic was. One exception was that the mentors found learning about a clinical chart less interesting than the mentees did; in addition, the mentees did not find learning about oral medicine and pathology as interesting as did the mentors in the first year of the program. Overall, the two groups did not differ in lecture evaluations in general nor in their level of interest in the two years.

The second type of program activities included hands-on activities and demonstrations such as group activities, circle discussions, exercises, visiting the clinics, setting up a cubicle, seeing the cassettes, learning about radiographs, waxing exercises, and drawing exercises. The mentees and mentors were exceptionally positive towards nearly all of these activities and did not differ in the degree to which 
Table 3. Mentors' and mentees' responses at beginning of programs in 2009 (Year 1) and 2010 (Year 2)

MENTORS:

At orientation session

\begin{tabular}{|c|c|c|c|c|c|c|}
\hline Year $^{\mathrm{a}}$ & 1 & 2 & 3 & 4 & 5 & $\begin{array}{c}\text { Mean } \\
\text { SD }\end{array}$ \\
\hline $1 \& 2$ & & & & $17 \%$ & $83 \%$ & $\begin{array}{c}4.83 \\
0.384\end{array}$ \\
\hline $1 \& 2$ & & & & $10 \%$ & $90 \%$ & $\begin{array}{c}4.90 \\
0.310\end{array}$ \\
\hline $1 \& 2$ & & & & $10 \%$ & $90 \%$ & $\begin{array}{c}4.90 \\
0.310\end{array}$ \\
\hline $1 \& 2$ & & & & $14 \%$ & $86 \%$ & $\begin{array}{c}4.86 \\
0.351\end{array}$ \\
\hline $1 \& 2$ & & & $3 \%$ & $31 \%$ & $66 \%$ & $\begin{array}{c}4.62 \\
0.561\end{array}$ \\
\hline $\begin{array}{l}\text { ienist, } \\
\text { me. }\end{array}$ & & & $3 \%$ & $14 \%$ & $83 \%$ & $\begin{array}{c}4.79 \\
0.491\end{array}$ \\
\hline Group & 1 & 2 & 3 & 4 & 5 & $\begin{array}{c}\text { Mean } \\
\text { SD }\end{array}$ \\
\hline Mentees & & & $27 \%$ & $27 \%$ & $46 \%$ & $\begin{array}{l}4.19^{*} \\
0.849\end{array}$ \\
\hline Mentors & & & & $14 \%$ & $86 \%$ & $\begin{array}{c}4.86 \\
0.351\end{array}$ \\
\hline Mentees & & & $19 \%$ & $31 \%$ & $50 \%$ & $\begin{array}{c}4.31 \\
0.788\end{array}$ \\
\hline Mentors & & & & $14 \%$ & $86 \%$ & $\begin{array}{l}4.86 * \\
0.351\end{array}$ \\
\hline Mentees & & & $27 \%$ & $27 \%$ & $46 \%$ & $\begin{array}{c}4.19 \\
0.849\end{array}$ \\
\hline Mentors & & & & $10 \%$ & $90 \%$ & $\begin{array}{c}4.90^{* *} \\
0.310\end{array}$ \\
\hline $\begin{array}{l}\text { ienist, } \\
\text { me. }\end{array}$ & $8 \%$ & $19 \%$ & $35 \%$ & $27 \%$ & $12 \%$ & $\begin{array}{c}3.15 \\
1.120\end{array}$ \\
\hline Mentors & & & & $19 \%$ & $81 \%$ & $\begin{array}{c}4.81 * * \\
0.402\end{array}$ \\
\hline
\end{tabular}

I feel that this will be the most satisfying career for me.

MENTEES AND MENTORS:

Beginning of Saturday 1

\begin{tabular}{|c|c|c|c|c|c|c|}
\hline Year $^{\mathrm{a}}$ & 1 & 2 & 3 & 4 & 5 & $\begin{array}{c}\text { Mean } \\
\text { SD }\end{array}$ \\
\hline $1 \& 2$ & & & & $17 \%$ & $83 \%$ & $\begin{array}{c}4.83 \\
0.384\end{array}$ \\
\hline $1 \& 2$ & & & & $10 \%$ & $90 \%$ & $\begin{array}{c}4.90 \\
0.310\end{array}$ \\
\hline $1 \& 2$ & & & & $10 \%$ & $90 \%$ & $\begin{array}{c}4.90 \\
0.310\end{array}$ \\
\hline $1 \& 2$ & & & & $14 \%$ & $86 \%$ & $\begin{array}{c}4.86 \\
0.351\end{array}$ \\
\hline $1 \& 2$ & & & $3 \%$ & $31 \%$ & $66 \%$ & $\begin{array}{c}4.62 \\
0.561\end{array}$ \\
\hline $\begin{array}{l}\text { ienist, } \\
\text { me. }\end{array}$ & & & $3 \%$ & $14 \%$ & $83 \%$ & $\begin{array}{c}4.79 \\
0.491\end{array}$ \\
\hline Group & 1 & 2 & 3 & 4 & 5 & $\begin{array}{c}\text { Mean } \\
\text { SD }\end{array}$ \\
\hline Mentees & & & $27 \%$ & $27 \%$ & $46 \%$ & $\begin{array}{l}4.19^{*} \\
0.849\end{array}$ \\
\hline Mentors & & & & $14 \%$ & $86 \%$ & $\begin{array}{c}4.86 \\
0.351\end{array}$ \\
\hline Mentees & & & $19 \%$ & $31 \%$ & $50 \%$ & $\begin{array}{c}4.31 \\
0.788\end{array}$ \\
\hline Mentors & & & & $14 \%$ & $86 \%$ & $\begin{array}{l}4.86^{*} \\
0.351\end{array}$ \\
\hline Mentees & & & $27 \%$ & $27 \%$ & $46 \%$ & $\begin{array}{c}4.19 \\
0.849\end{array}$ \\
\hline Mentors & & & & $10 \%$ & $90 \%$ & $\begin{array}{c}4.90^{* *} \\
0.310\end{array}$ \\
\hline Mentees & $8 \%$ & $19 \%$ & $35 \%$ & $27 \%$ & $12 \%$ & $\begin{array}{c}3.15 \\
1.120\end{array}$ \\
\hline Mentors & & & & $19 \%$ & $81 \%$ & $\begin{array}{c}4.81 * * \\
0.402\end{array}$ \\
\hline
\end{tabular}

When I think about a future as a dentist/dental hygienist, I feel that this will be the most satisfying career for me.

Note: Responses ranged from $1=$ strongly disagree to $5=$ strongly agree.

andependent sample t-tests showed that the average responses in 2009 and 2010 were not significantly different.

${ }^{*} \mathrm{p} \leq 0.01 ;{ }^{* *} \mathrm{p} \leq 0.001$

Table 4. Mentors' and mentees' average responses concerning their interest in the program in weeks 2-4, 7, 10, and 11

\begin{tabular}{|c|c|c|c|c|c|c|}
\hline \multirow[t]{2}{*}{ Week } & \multicolumn{2}{|c|}{$\begin{array}{l}\text { I look forward to } \\
\text { next Saturday }\end{array}$} & \multicolumn{2}{|c|}{$\begin{array}{c}\text { Today was interesting/ } \\
\text { went well }\end{array}$} & \multicolumn{2}{|c|}{$\begin{array}{l}\text { I got to know the } \\
\text { mentee/mentor better }\end{array}$} \\
\hline & Mentee $^{\mathrm{a}}$ & Mentor $^{\mathrm{a}}$ & Mentee & Mentor & Mentee & Mentor $^{\mathrm{b}}$ \\
\hline 2 & $\mathrm{n} / \mathrm{a}$ & 4.68 & 4.35 & 4.42 & 4.23 & 4.42 \\
\hline 3 & 4.33 & 4.58 & 4.33 & 4.38 & 4.13 & 4.24 \\
\hline 4 & 4.39 & 4.53 & 4.29 & 4.26 & 4.14 & 4.11 \\
\hline 7 & 4.60 & 4.62 & 4.30 & 4.03 & 3.85 & 3.57 \\
\hline 10 & 4.71 & 4.43 & 4.71 & 4.26 & 4.14 & 4.13 \\
\hline 11 & 4.91 & 4.68 & 4.70 & 4.79 & 4.39 & 4.11 \\
\hline
\end{tabular}

Note: Responses ranged from $1=$ strongly disagree to $5=$ strongly agree.

andependent sample t-tests showed that average responses for mentees and mentors in 2009 and 2010 were not significantly different. ${ }^{b}$ Independent sample t-tests showed that average responses of mentees and mentors did not differ significantly. 


\begin{tabular}{|c|c|c|}
\hline The information about \{\} was interesting & Mentees & Mentors \\
\hline Saturday 1: pediatric dentistry & 4.16 & 4.50 \\
\hline Saturday 2: oral health from 0 to 18 years & 4.23 & 4.16 \\
\hline Saturday 3: caries & 4.30 & 4.23 \\
\hline Saturday 3: periodontal disease & 4.40 & 4.27 \\
\hline Saturday 3: having no teeth & 4.27 & 4.38 \\
\hline Saturday 3: dental hygiene & 4.34 & 4.35 \\
\hline Saturday $7:$ HIPAA & 3.55 & 3.32 \\
\hline Saturday 7: medical/dental history & 4.11 & 4.21 \\
\hline Saturday 8: sterilization (only Year 1 ) & 4.33 & 4.22 \\
\hline Saturday 8: dispensing (only Year 2) & 4.00 & 3.67 \\
\hline Saturday 9: the clinical chart & 4.33 & $3.39^{*}$ \\
\hline Saturday 10: volunteering & 4.29 & 3.83 \\
\hline Saturday 10: the clinic next Saturday & 4.50 & 4.13 \\
\hline Saturday 11 : how to educate a patient & 4.64 & 4.53 \\
\hline Saturday 12: prosthodontics & 3.33 & $2.53^{*}$ \\
\hline Saturday 13: oral medicine/pathology & 3.58 & $4.27^{* *}$ \\
\hline Saturday 13: orthodontics & 3.64 & 4.00 \\
\hline Saturday 13: hospital dentistry & 4.00 & $4.72 *$ \\
\hline Saturday 14: preclinical dentistry & 4.56 & 4.60 \\
\hline Saturday 14: dental school admission & 4.33 & $4.80^{*}$ \\
\hline Saturday 14: dental hygiene admission & 4.11 & 4.60 \\
\hline
\end{tabular}

they enjoyed participating in these events (Table 6). Again, the evaluations in the first and second years did not differ. The third type of program activities focused on contacts with patients (Table 7). The students prepared a health fair in their high school for children and parents and then conducted this health fair. These activities were positively evaluated by the mentees and the mentors. The high school students also had an opportunity to shadow their mentors when they provided dental care for children during a "Give Kids a Smile" clinic and on a second Saturday when they provided volunteer services for adult patients. Both mentees and mentors evaluated these experiences very positively.

At the end of the program, the mentees responded to a survey in 2009-10 and 2010-11, and the mentors responded to an end of program evaluation in the 2009-10 year (Table 8). The mentees agreed in Year 1 that the program was interesting. However, in Year 2 all mentees agreed strongly that the program had been interesting. The mentee evaluations concerning how much they learned about dental hygiene and dentistry were also significantly higher in the 2010-11 than in the 2009-10 school year. Overall, the mentees were sure that they wanted to go to college and had thought quite a bit about becoming a dental hygienist or a dentist.

One crucial component of this program was the mentoring relationship. The high school students were quite satisfied with their mentors (Table 8). They rated them as very friendly, found it easy to talk to them, and were comfortable talking with their mentors. In 2009-10, 60 percent of the mentees and 100 percent of the mentors wanted to keep in touch with their mentor/mentee after the end of the official program.

\section{Discussion}

Figure 1 provides an overview of the program objectives and how these objectives addressed the three major challenges in dentistry and dental education. Objective 1 was to recruit URM/LI Ypsilanti High School students into the program and motivate them to consider dentistry-related careers, thus ultimately contributing to increasing the numbers of URM/LI dental providers. The survey data reported in Tables 3 through 8 show the mentees' overall interest in the program and their very positive evaluations 
Table 6. Mentees' and mentors' evaluations of program activities in 2009-10 and 2010-11

\begin{tabular}{|c|c|c|c|}
\hline Type of Activity & Year $^{\mathrm{a}}$ & Mentees & Mentors ${ }^{b}$ \\
\hline Saturday 1 : The website is interesting. & $1 \& 2$ & 4.35 & 4.29 \\
\hline Saturday 2: The web treasure hunt was fun. & $1 \& 2$ & 3.90 & 4.32 \\
\hline Saturday 2: The web treasure hunt allowed me to speak with a mentor. & $1 \& 2$ & 4.26 & 4.26 \\
\hline Saturday 2: Including general career activities at the end is a good idea. & $1 \& 2$ & 4.45 & 4.79 \\
\hline Saturday 3: The web activity got us started well. & $1 \& 2$ & 4.03 & 4.33 \\
\hline Saturday 3: The web activity allowed me to connect with my mentor. & $1 \& 2$ & 3.63 & 4.20 \\
\hline Saturday 4: The group activities got us started well. & $1 \& 2$ & 4.35 & 4.08 \\
\hline Saturday 4: The group activities allowed me to connect with my mentor. & 1 & 3.82 & 4.27 \\
\hline Saturday $6:$ The circle discussion got us started well. & 1 & 4.36 & 4.19 \\
\hline Saturday 6 : The discussion of the health fair went well. & 1 & 4.36 & 4.27 \\
\hline Saturday 6: I liked the discussion of what we learned so far. & 1 & 4.21 & 4.19 \\
\hline Saturday 6: The group activities allowed me to connect with my mentor. & 1 & 4.43 & 4.06 \\
\hline Saturday 7: The lead and be led exercise was fun. & 1 & 3.79 & 4.39 \\
\hline Saturday 8: Visiting the clinics was a good idea. & 1 & 4.67 & 4.56 \\
\hline Saturday 8: Learning how to set up a cubicle was interesting. & 1 & 4.67 & 4.44 \\
\hline Saturday 8: Seeing the cassettes was interesting. & 1 & 3.92 & 4.22 \\
\hline Saturday 8: The treasure hunt was fun. & 1 & 4.58 & 4.67 \\
\hline Saturday 9: Learning about radiographs was interesting. & & 4.70 & 4.72 \\
\hline Saturday 10: The treasure hunt was fun. & 1 & 5.00 & 4.69 \\
\hline Saturday 12 : The waxing exercise was great. & 1 & 5.00 & 4.89 \\
\hline Saturday 12 : The drawing exercises were fun. & 1 & 4.00 & 4.44 \\
\hline
\end{tabular}

Note: Responses ranged from $1=$ strongly disagree to $5=$ strongly agree.

andependent sample t-tests showed that average responses for mentees and mentors in 2009-10 and 2010-11 were not significantly different.

${ }^{\mathrm{b}}$ Independent sample t-tests showed that average responses of mentees and mentors did not differ significantly.

Table 7. Mentees' and mentors' evaluations of program activities concerning patients

Type of Activities Involving Patients

\begin{tabular}{ccc} 
Year $^{\mathrm{a}}$ & Mentees & Mentor $^{\mathrm{b}}$ \\
\hline 1 & 4.33 & 4.00 \\
1 \& 2 & 4.50 & 4.32 \\
1 \& 2 & 3.70 & 3.22 \\
$1 \& 2$ & 4.70 & 4.79 \\
1 \& 2 & 4.65 & 4.74 \\
1 & 4.20 & 4.43 \\
1 & 4.55 & 4.22 \\
1 & 4.45 & 3.94
\end{tabular}

Saturday 3: The preparation for the health fair went well.

Saturday 4: The preparation for the health fair went well.

Saturday 7: Doing the HIPAA certification was interesting.

Saturday 11: Being in the clinic upstairs was interesting.

Saturday 11: Watching how children get treated was interesting.

Saturday 12: Discussing the procedures done at "Give Kids a Smile" clinic was interesting.

Saturday 14: Being in the clinic upstairs was interesting.

Saturday 14: Watching how adults get treated was interesting.

3.94

Note: Responses ranged from $1=$ strongly disagree to $5=$ strongly agree.

andependent sample t-tests showed that average responses for mentees and mentors in 2009-10 and 2010-11 were not significantly different.

${ }^{\mathrm{b}}$ Independent sample t-tests showed that average responses of mentees and mentors did not differ significantly.

of the mentoring and educational activities. However, several other outcomes should be mentioned. First, the fact that more than twenty high school students were willing to attend this program regularly on fifteen Saturday mornings during the fall and winter speaks for itself. These high school students were eager to learn and worked hard. Their commitment was outstanding. Given that no school busses took the students to school on Saturday mornings, some of the students without personal transportation often walked a long way to their high school to participate in the programs. Anecdotal evidence came from conversations with parents and family members at the end of the program ceremony and lunch. One mother thanked the program coordinators and told them that her daughter had never been interested in academics but now was determined to go to college. One father described how nobody in 
Table 8. Mentees' and mentors' end of program evaluations

\begin{tabular}{|c|c|c|c|}
\hline & Yearc & Mentees & Mentors \\
\hline \multicolumn{4}{|l|}{ Program Evaluations and Outlook on Future } \\
\hline The program was interesting. ${ }^{a}$ & $\begin{array}{l}1^{*} \\
2\end{array}$ & $\begin{array}{l}4.00 \\
5.00\end{array}$ & $\begin{array}{c}4.38 \\
-\end{array}$ \\
\hline I learned a lot about how to keep my teeth healthy. ${ }^{a}$ & 1 & 4.08 & 4.32 \\
\hline I learned a lot about what dental hygiene is all about. ${ }^{a}$ & $\begin{array}{c}1 * * \\
2\end{array}$ & $\begin{array}{l}4.17 \\
5.00\end{array}$ & $\begin{array}{c}3.88 \\
-\end{array}$ \\
\hline I learned a lot about what dentistry is all about. ${ }^{a}$ & $\begin{array}{c}1^{* *} \\
2\end{array}$ & $\begin{array}{l}4.17 \\
5.00\end{array}$ & $\begin{array}{l}4.25 \\
\mathrm{n} / \mathrm{a}\end{array}$ \\
\hline At this point, how sure are you that you want to go to college? ${ }^{b}$ & 1 & 4.82 & $\mathrm{n} / \mathrm{a}$ \\
\hline At this point, how sure are you about which profession you would like to be in? ${ }^{\mathrm{b}}$ & 1 & 4.44 & $\mathrm{n} / \mathrm{a}$ \\
\hline $\begin{array}{l}\text { How much do you think about becoming } \\
\text { a dental hygienist? } \\
\text { a dentist? } \\
\text { a nurse? } \\
\text { a medical doctor? }\end{array}$ & 1 & $\begin{array}{l}3.75 \\
4.38 \\
3.07 \\
3.45\end{array}$ & $\mathrm{n} / \mathrm{a}$ \\
\hline \multicolumn{4}{|l|}{ Mentor/Mentee-Related Questions } \\
\hline Did you ever communicate with your mentor/ee outside of class? \% Yes & 1 & $100 \%$ & $100 \%$ \\
\hline $\begin{array}{l}\text { How did you communicate with your mentor/ee outside of class? \% Yes } \\
\text { email } \\
\text { text } \\
\text { call }\end{array}$ & 1 & $\begin{array}{l}100 \% \\
100 \% \\
100 \%\end{array}$ & $\begin{array}{l}100 \% \\
100 \% \\
100 \%\end{array}$ \\
\hline How comfortable were you to talk with your mentor/ee? & $1 \& 2^{* *}$ & 4.50 & 4.25 \\
\hline How friendly was your mentor/ee? ${ }^{\mathrm{b}}$ & $1 \& 2$ & $4.89 *$ & 4.13 \\
\hline How easy was it to talk to your mentor/ee? ${ }^{\mathrm{b}}$ & $1 \& 2$ & 4.61 & 4.00 \\
\hline $\begin{array}{l}\text { Do you think you will keep in touch with your mentor/ee? } \\
\% \text { Yes } \\
\% \text { Maybe }\end{array}$ & 1 & $\begin{array}{l}60 \% \\
40 \%\end{array}$ & $\begin{array}{c}100 \% \\
0 \%\end{array}$ \\
\hline $\begin{array}{l}\text { Would you be interested in being a peer mentor next year? } \\
\% \text { Yes } \\
\% \text { Maybe } \\
\text { Mentor will leave area }\end{array}$ & $1 \& 2$ & $\begin{array}{c}92 \% \\
8 \%\end{array}$ & $\begin{array}{l}25 \% \\
13 \% \\
63 \%\end{array}$ \\
\hline \multicolumn{4}{|c|}{$\begin{array}{l}\text { a Responses ranged from } 1=\text { strongly disagree to } 5=\text { strongly agree. } \\
\text { bResponses ranged from } 1=\text { not at all to } 5=\text { very. } \\
\text { cWhen independent sample t-tests showed that answers in Year } 1 \text { and } 2 \text { were not significantly different, the responses were analyzed for } \\
\text { both years combined. }\end{array}$} \\
\hline${ }^{*} p \leq 0.05 ; * * p \leq 0.01$ & & & \\
\hline
\end{tabular}

his family had ever wanted to go to college but now his son told him that he would work very hard to get a wrestling scholarship because he thought there was no other way to finance a college education. One student is still in contact with the first author and is determined to make it into dental school. If there is ever a question whether there are "enough" URM students who might be interested in going to dental school, ${ }^{35}$ then this program can provide an answer.
Just as decisively, it shows that early outreach to high school students over a prolonged period of time can make a difference. ${ }^{16}$

The second objective of the program was to provide opportunities for dental and dental hygiene students to engage in educational activities and mentor these high school students. While no systematic follow-up data were collected about these students' professional activities after their recent graduation, 
the majority of the dental students are currently enrolled in specialty programs, and one former dental student works for ADEA. It will be interesting to see in five to ten years how many of these students have part-time or full-time academic careers. However, even if the mentors decide to become dental practitioners in private practice, their experiences may have raised their awareness concerning the lives of a part of the population to which they might not otherwise have had access. Spending fifteen Saturdays mentoring a group of high school students provided the dental and dental hygiene students many opportunities to learn about the struggles of these adolescents. Overall, it was admirable that the dental and dental hygiene students gave up their Saturday mornings plus one lunch hour each week to help create and conduct this program. It was powerful for the main organizer of the program (MRI) to see the commitment of these very busy dental and dental hygiene students and their efforts to make this program work.

The third objective was to bring dental care to underserved children in this community. While one health fair per year might not seem like a major contribution to solving this challenge, it was nevertheless a way to engage the high school students in reflections concerning the need to bring oral health care to their community.

At least three lessons were learned from this program. First, it was encouraging to see that the school district and the administrators were very happy to collaborate with the dental school and went out of their way to make this program happen. Second, several characteristics of this program might have contributed to its success. Many of the dental and dental hygiene students and some of the participating faculty members were from URM groups and LI backgrounds themselves and were willing to share their stories about how they overcame obstacles. This may have made it easier for the high school students to see those individuals as role models. It also seemed important to conduct a program over a longer period of time. ${ }^{36}$ Merely presenting information about dental careers once or twice to high school students would most likely not have had the same impact on their lives. In addition, each Saturday morning program started with a breakfast, and food was also provided during the breaks. Sharing breakfast and snacks also provided opportunities for the mentors and mentees to connect on a personal level.

A third lesson concerned the role of the dental and dental hygiene students. It seemed important to give them autonomy in creating educational presentations and organizing program activities. ${ }^{27,28}$ These students were closer in age to the high school students and were thus more effective in communicating with these students than older faculty members. They did a marvelous job in engaging the high school students and truly learned a lot about educational activities. They undoubtedly earned the credit for the elective courses in which they were enrolled.

The major challenge encountered, and the reason this program was not continued, was related to funding. The first year of the program was supported by a grant from the Kellogg Foundation and ADEA. Due to budget constraints, discretionary funds from the dental school were not available to support the program after the grant ended. Thus, the second year of this program was conducted with limited funding from the Center for Educational Outreach at the University of Michigan to cover bus transportation from the high school to the dental school from January through March 2011. If dental schools want to contribute to overcoming the three major challenges that dentistry and dental education face (see Figure 1), they have to become creative and explore new ways to address these issues.

\section{Conclusion}

This project demonstrated that engaging URM/ LI high school students in a program about dentistry and dental careers increased their interest in attending college and preparing to enter health-related professions. Involving dental and dental hygiene students in mentoring and educational activities was evaluated very positively by these students. Finally, a pipeline program for high school students was developed that can be shared with other dental schools.

\section{Acknowledgments}

This project was supported by a grant from the American Dental Education Association and the W.K. Kellogg Foundation (PIs: Stefanac and Inglehart) from June 1, 2009, to May 31, 2010, plus a no-cost extension through August 2010. In January to March 2011, the cost for the busses used for transporting the high school students on eight Saturdays from their high school to the University of Michigan School of Dentistry was paid by the University of Michigan Center for Educational Outreach (CEO). We want to thank Dr. William Collins, Director of 
the CEO, for his support of this program. We also want to thank the Ypsilanti school district, especially Superintendent Dr. James Hawkins, who agreed to collaborate with us; Assistant Superintendent Mr. Richard Weigel and Principal Mr. Jonathan Brown, who codeveloped the program with the dental school team in the 2009-10 school year; and Superintendent Mr. Dedrick Martin and Principal Mr. Jerry Fouchey, who made the program possible in the 2010-11 school year. We want to thank the dental and dental hygiene students who served as mentors and codeveloped and contributed immensely to this program. In addition, we want to thank six dental faculty members, Drs. Arruda, Kanjirath, Malcheff, McCauley, Taylor, and Zwetchkenbaum, and two dental school staff members, Ms. Patricia Katcher from Student Affairs and Ms. Cheryl Quiney from Patient Services, who were willing to join the students during a Saturday morning session to talk to them about their work. We also want to thank Dr. Estrella and the pediatric dentistry graduate students who conducted oral health screenings during health fairs at the high school in November 2009 and 2010.

\section{REFERENCES}

1. Oral health in America: a report of the surgeon general. Rockville, MD: U.S. Department of Health and Human Services, National Institutes of Health, National Institute of Dental and Craniofacial Research, 2000.

2. Sullivan Commission on Diversity in the Healthcare Workforce. Missing persons: minorities in the health professions. At: www.aacn.nche.edu/media-relations/ SullivanReport.pdf. Accessed: March 9, 2013.

3. Unequal treatment: confronting racial and ethnic disparities in health care. An Institute of Medicine Report. Washington, DC: National Academies Press, 2002.

4. Formicola AJ, Stavisky J, Lewy R. Cultural competence: dentistry and medicine learning from one another. J Dent Educ 2003;67(8):869-75.

5. Andersen RM, Carreon DC, Davidson PL, et al. Who will serve? Assessing recruitment of underrepresented minority and low-income dental students to increase access to dental care. J Dent Educ 2010;74(6):579-92.

6. Albino JE, Inglehart MR, Tedesco LA. Dental education and changing oral health care needs: disparities and demands. J Dent Educ 2012;76(1):75-88.

7. Price SS, Crout RJ, Mitchell DA, et al. Increasing minority enrollment utilizing dental admissions workshop strategies. J Dent Educ 2008;72(11):1268-76.

8. Gravely T, McCann A, Brooks E, et al. Enrichment programs at dental schools: impact on enrollment of underrepresented minority students. J Dent Educ 2008;68(5):542-52.

9. Markel G, Woolfolk M, Inglehart MR. Feeding the pipeline: academic skills training for predental students. J Dent Educ 2008;72(6):653-61.
10. Johnson KP, Woolfolk MW, May KB, Inglehart MR. Effect of an enrichment program on DAT scores of potential dental students from disadvantaged backgrounds. J Dent Educ 2013;77(8):1063-71.

11. McCants JB. Methods to increase underrepresented minority student enrollment and retention at the University of Louisville School of Dentistry. J Dent Educ 2011;75(12):1542-7.

12. McClain MA, Jones FR, McClain CR, Curd FM. Increasing dental student diversity through the UNLV dental prospects program. J Dent Educ 2013;77(5):547-52.

13. Lacy ES, McCann AL, Miller BH, et al. Achieving student diversity in dental schools: a model that works. J Dent Educ 2012;76(5):523-33.

14. Arnett MR, Forde R. Increasing student diversity and cultural competence as part of Loma Linda University School of Dentistry's service mission. J Dent Educ 2012;76(6):721-7.

15. Wides CD, Brody HA, Alexander CJ, et al. Long-term outcomes of a dental postbaccalaureate program: increasing dental student diversity and oral health access. J Dent Educ 2013;77(5):536-46.

16. Formicola AJ, Klyvert M, Thompson A, et al. Creating an environment for diversity in dental schools: one school's approach. J Dent Educ 2003;67(5):491-9.

17. Furlong A. Where are the minority dentists? What statistics won't tell you. AGD Impact 1999;27(10):4-9.

18. Brooks ES, Gravely TC, Hornback SA, et al. Bridge to dentistry: one dental school's approach to improving its enrollment of underrepresented minorities. J Am Coll Dent 2002;69(1):23-30.

19. Wadenya RO, Lopez N. Parental involvement in recruitment of underrepresented minority students. J Dent Educ 2008;72(6):680-7.

20. John V, Papageorge M, Jahangiri L, et al. Recruitment, development, and retention of dental faculty in a changing environment. J Dent Educ 2011;75(11):82-9.

21. Gates P, Ubu N, Smithey L, et al. Faculty development for underrepresented minority dental faculty and residents. J Dent Educ 2013;77(3):276-91.

22. Okwuje I, Sisson A, Anderson E, Valachovic RW. Dental school vacant budgeted faculty positions, 2007-08. J Dent Educ 2009;73(12):1415-22.

23. Rupp JK, Jones DL, Seale NS. Dental students' knowledge about careers in academic dentistry. J Dent Educ 2006;70(10):1051-60.

24. Chmar JE, Weaver RG, Valachovic RW. Dental school vacant budgeted faculty positions, academic years 200506 and 2006-07. J Dent Educ 2008;72(3):370-85.

25. Bertolami CN. Creating the dental school faculty of the future: a guide for the perplexed. J Dent Educ 2007;71(10):1267-80.

26. Sinkford JC, Valachovic RW, Weaver RG, West JF. Minority dental faculty development: responsibility and challenge. J Dent Educ 2010;74(12):1388-93.

27. McAndrew M, Brunson WD, Kamboj K. A survey of U.S. dental school programs that help students consider academic careers. J Dent Educ 2011;75(11):1458-64.

28. Gironda MW, Bibb CA, Lefever K, et al. A program to recruit and mentor future academic dentists: successes and challenges. J Dent Educ 2013;77(3):292-9. 
29. Weaver RG, Haden NK, Valachovic RW. Dental school vacant budgeted faculty positions: academic year 2000-01. J Dent Educ 2001;65(11):1291-302.

30. Casamassimo PS, Harms KA, Parrish JL, Staubach JW. Future of dentistry: the dental workforce. J Am Dent Assoc 2002;133(9):1226-35.

31. U.S. Census Bureau State and County QuickFacts. Data derived from population estimates, American community survey, census of population and housing, county business patterns, economic census, survey of business owners, building permits, consolidated federal funds report, census of governments. At: http://quickfacts.census.gov/ qfd/states/26/2689140.html. Accessed: March 11, 2013.

32. U.S. Census Bureau. 2007-11 American community survey. At: http:/factfinder2.census.gov/faces/tableservices/ jsf/pages/productview.xhtml?src=bkmk. Accessed: March 11,2013
33. Ypsilanti, Michigan. At: www.city-data.com/city/Ypsilanti-Michigan.html\#ixzz2N3q68D2r. Accessed: March 9, 2013.

34. District of Ypsilanti annual education report 2011-12. At: www.ypsd.org/downloads/district_docs/districtaer 2011-12a1_20120820_103106_7.pdf. Accessed: March 11,2013

35. Woolfolk MW, Price SS. Dental education: evolving student trends. J Dent Educ 2012;76(1):51-64.

36. Wadenya RO, Schwartz S, Lopez N, Fonseca R. Strategies for recruitment and retention of underrepresented minority students at the University of Pennsylvania School of Dental Medicine. J Dent Educ 2003;67(9):1039-41. 